\title{
Historias que brotan de las rocas. Experiencias sobre el Pedregal de San Ángel y su reserva ecológica
}

\begin{abstract}
Zambrano González, L., \& Cano Santana, Z. (Comps.). (2016). Historias que brotan de las rocas. Experiencias sobre el Pedregal de San Ángel y su reserva ecológica (325 pp., ISBN 9786078328703). México: Universidad Nacional Autónoma de México y Comisión Nacional para el Conocimiento y Uso de la Biodiversidad.
\end{abstract}

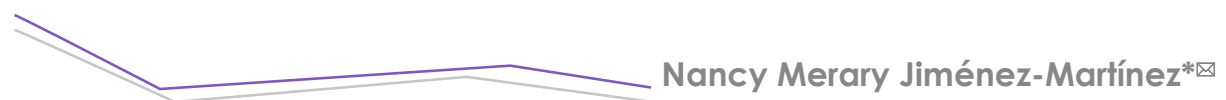

Jiménez-Martínez, N. M. (2018). Historias que brotan de las rocas. Experiencias sobre el Pedregal de San Ángel y su reserva ecológica [Reseña de libro]. Investigación y Ciencia de la Universidad Autónoma de Aguascalientes, 26(75), 87-88.

La inminente destrucción ambiental ha orillado al surgimiento de esquemas que buscan su defensa y salvaguardia; la protección de los ecosistemas naturales corresponde a uno de dichos esquemas. Historias que brotan de las rocas cuenta, a diferentes voces, el surgimiento de la Reserva Ecológica del Pedregal de San Ángel de Ciudad Universitaria (REPSA), un instrumento con el que se ha protegido una fracción del extraordinario patrimonio geoecológico creado por el derrame de lava del volcán Xitle, hace dos milenios en la cuenca del Valle de México.

Se trata de una obra distinguida con mención honorífica en la categoría de divulgación en la decimonovena edición del Premio Antonio García Cubas 2017 al mejor libro y labor editorial en Antropología e Historia. Es resultado de un esfuerzo extraordinario convocado por sus compiladores y realizado por más de 30 autores que en ella participaron para celebrar los primeros 30 años de vida de la REPSA.

El propósito del libro es reconstruir y documentar, a partir de los distintos testimonios contados en primera persona, la historia del Pedregal de San Ángel, ámbito de invaluable riqueza biológica que ha sido objeto de disputa ante el apremiante crecimiento de Ciudad Universitaria (CU) de la UNAM

\footnotetext{
* Centro Regional de Investigaciones Multidisciplinarias, Universidad Autónoma del Estado de México. Av. Universidad s/n, Circuito 2, Col. Chamilpa, Ciudad Universitaria, C. P. 62210, Cuernavaca, Morelos, México. Correo electrónico: njimenez@correo.crim.unam.mx

$\bowtie$ Autor para correspondencia
}

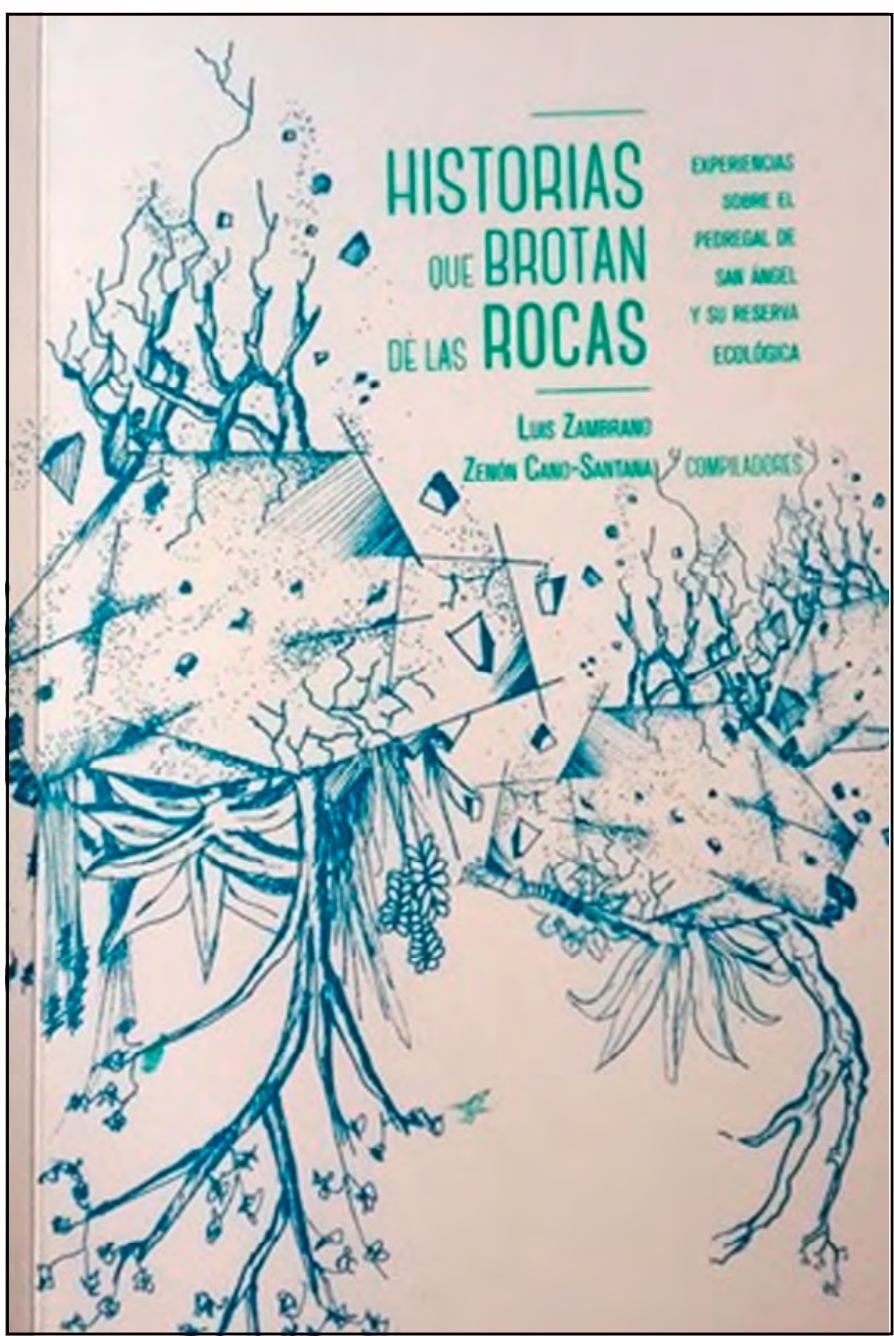

Portada del libro Historias que brotan de las rocas. Experiencias sobre el Pedregal de San Ángel y su reserva ecológica. 
IחVESTIGAGIÓn Y GIEnCIA DE LA UNIVERSIDAD AUTÓNOMA

88 DE RGUASCALIERTES y el interés por asegurar su conservación. Relata el esfuerzo de estudiantes y académicos por hacer de dicha tarea una responsabilidad universitaria en los desafíos que su preservación supone. El libro destaca los complejos problemas que los actores experimentan ante una figura de protección ambiental como lo es la reserva ecológica, desde su creación hasta su gestión y mantenimiento.

El libro se organiza en cuatro grandes secciones que guardan un orden cronológico y teóriconarrativo. La Parte I, titulada "El principio", recoge las voces de los primeros exploradores científicos del Pedregal, quienes durante las décadas de 1950 y 1960 documentaron su importancia en términos de la diversidad biológica del lugar. La Parte II, "Orígenes de la Reserva Ecológica", expone la pluralidad de experiencias de los actores durante el tenso proceso de elaboración del proyecto de creación de la reserva ecológica en el corazón de CU y dentro de una mega urbe como la Ciudad de México. Se trata de los relatos de aquellos jóvenes estudiantes y sus profesores, quienes vincularon valientemente un ejercicio académico con la que quizá fue la primera movilización de carácter medioambiental en México, para exigir la protección y defensa de este valioso territorio, que también fue su laboratorio de investigación.

La Parte III, "Ya tenemos una reserva ecológica ¿qué hacemos?", cuenta las experiencias de quienes en sus tareas cotidianas se enfrentaron a los desafíos propios de ejecutar este instrumento de conservación en el escenario de la Universidad de la
Nación; es decir, de las dificultades que surgen por la convergencia de contar con capacidades extraordinarias con presupuestos siempre limitados. De este modo se encuadra lo que ha sido el desarrollo de las tareas fundamentales para el establecimiento y regulación de las actividades de investigación, docencia y difusión de la cultura de este importante ecosistema. La Parte IV, "...Y brotan las historias", se compone de los relatos de cuatro académicos, quienes con emoción exponen ampliamente cómo sus experiencias profesionales y personales han estado íntimamente vinculadas a la reserva.

El valor de esta obra va más allá del esfuerzo por rescatar y compartir la memoria colectiva de la creación de la REPSA. Propone aprender de la historia del Pedregal de San Ángel las estrategias para superar las brechas de una dicotomía no resuelta en la planeación en México: aquella que se libra entre la construcción y la conservación.

La REPSA, como muchos otros socioecosistemas, ha sido y es objeto de disputa. Su gestión y manejo son procesos altamente intrincados no solo por la vulnerabilidad biológica del territorio o por su ubicación dentro de un campus universitario en una gran metrópoli, sino por las relaciones que se establecen entre ambas dimensiones; es decir, por la interacción entre los elementos naturales y sociales que la componen. Una de las tareas de la planeación para superar dicha dicotomía es reconocer y valorar esas interacciones. Las historias que brotan de las rocas tienen mucho qué enseñarnos al respecto. 